\title{
Eritrea's Relation with IGAD and the OAU/AU: The Domestic and International Dynamics
}

\section{Befekadu Bogale*}

\begin{abstract}
:
The state of Eritrea joined the club of sovereign states on early years of the 1990s. Though many were optimist of the new state's contribution for enhanced interstate cooperation in the volatile horn of Africa region, the early years' optimism never stayed longer and the Eritrean state soon begun to collide with the states of the region and beyond. Since the mid-1990s, relationship between the state of Eritrea and her four immediate neighbors i.e. Sudan, Yemen, Ethiopia and Djibouti, have witnessed irregularities ranging from diplomatic confrontation to armed clashes. The armed clashes ranged from the bloody Ethio-Eritrean war of 1998 to 2000, which was estimated to have consumed the life of about 70,000 individuals from both sides, to the minor and ad hoc clashes with the forces Djibouti in June 2008. The Eritrean state's rough relation with the neighboring states is replicated as far as the relationship with the Intergovernmental Organizations is concerned. Particularly, the state's relationship with the African Intergovernmental Organizations is irregular for large part to date. On these background, this article tries to explicit the dynamics of foreign policy and relations of Eritrea focusing on the country's relation with the two African Intergovernmental Organizations (one sub-regional and the other regional) by using historical descriptive methodology and the three major levels of analysis in international relations as the framework of analysis.
\end{abstract}

Key Words: $\quad$ Eritrea, Levels of Analysis, Intergovernmental Organizations

* Graduated Addis Ababa University with B.A in Political Science and International Relations (July 2009) and M.A in International Relations (June 2013) and currently serving as lecturer at the Dire Dawa University. 
Befekadu Bogale

\section{Introduction}

One of the characteristic features of the contemporary international system is the increased incidence of Intergovernmental Organizations (IGOs). IGOs are transnational structures created by formal agreement between at least three states. ${ }^{1}$ Their membership may be from all around the world (like the United Nations (UN)), from one geographic region (like the European Union and the African Union (AU)) or from certain sub-region (like the North American Free Trade Agreement (NAFTA) and the Intergovernmental Authority on Development (IGAD)). The foundational basis for IGOs is commonality of issues affecting the states and the belief that the IGOs increase efficiency of the states' collective activities and allow timely reactions. ${ }^{2}$ In addition to allowing collective actions, IGOs constrain activities of the member states by creating rules of behavior, through surveillance of the states' behavior and information sharing. ${ }^{3}$

It is under this general background that the independent Eritrea's relation with the subregional IGO IGAD and the regional IGO AU has to be looked at. Eritrea joined the Intergovernmental Authority on Drought and Desertification (IGADD), predecessor of IGAD, in 1993 as the seventh ${ }^{4}$ member state. Similarly, Eritrea's membership of the Organization of African Unity (OAU), predecessor of the AU, came immediately after the achievement of dejure recognition in 1993.

This article attempts to examine the dynamics of independent Eritrea's relation with the IGAD and the OAU/AU arguing that Eritrea's relation with the two organizations is characterized by ups and downs largely rooted in Eritrean regime's policies towards the neighboring states and the legacy of independence struggle. In terms of structure, the article is organized into an introductory and three main sections. The second section is devoted to discussion of the levels of analysis in international relations. Throughout the article, all the three major levels of analysis are adopted on belief that the overall trend of Eritrea's relation with the IGAD and the OAU/AU can be holistically understood by taking into consideration the individual, state and system level factors operating in the domestic and international contexts. In the third section, substantive issues related to Eritrea's relation with the IGAD and the OAU/AU are examined. The fourth section discusses factors affecting Eritrea's foreign policy and relations focusing on the country's relation with the two IGOs. Lastly, the article ends with brief concluding remarks.

\section{Conceptual Framework: Levels of Analysis in International Relations}

Broadly defined level of analysis refers to the analytical tool via which inquiry and explanations about certain phenomena are made on vertically distinct planes. ${ }^{5}$ There are three widely used levels of analysis in the field of international relations: individual, state and international levels.

The individual level of analysis is a level in which the focus is on perceptions, values, or idiosyncrasies of the individual decision makers. ${ }^{6}$ That is, the individual level of analysis allows detailed examination of the impact of individuals on foreign policy and helps to understand the influence of psychology, perception, school and family background, ideological and religious beliefs of an individual on his/her decision making. ${ }^{7}$ Thus, the major emphasis at this level is on the behavior of policy makers as explanations for particular foreign policy decisions and actions.

The state level of analysis is an intermediate level between the individual and system levels where the focus is on features of the state and their impact on foreign policy behavior of that state. ${ }^{8}$ In other words, the state of level of analysis emphasizes on the impact of domestic factors such as the 
nature of political system, geographic location, political history, public opinion, size of the country and economy on foreign policy and relations of a state. ${ }^{9}$ Therefore, the processes of national goal formulation, factors affecting the processes and the institutions involved in those processes are of central importance at the state level of analysis. ${ }^{10}$ Thus, the focus at this level is on the internal or domestic causes of the state's external policies.

The system level is the most comprehensive level of analysis where the emphasis is on the importance of international conditions in shaping policies and actions of the states. The influencing factors at this level include international norms and laws, international institutions, economic and technical interdependence, international power structure and activities of the Multinational Corporations. ${ }^{11}$

As regards to the environment of foreign policy, the three levels of analysis are categorized into two: domestic and international. Domestic environment of foreign policy encompasses all the influencing factors from within the state whereas the international context consists forces which are 'exogenous' to the state but have bearing on its policies and external behavior. Therefore, the system level factors such as international law, power distribution, nature of the world economy and the policies and actions of other states all constitute the international environment of foreign policy of any state. ${ }^{12}$ On the other hand, geographic and topographic characteristics, security needs, population, government structure and philosophy, public opinion, leaders' quality and leadership style are internal or domestic factors affecting any state's foreign policy. ${ }^{13}$

\section{Eritrea's Relation with the IGAD and the OAU/AU}

This section is concerned with account of the independent Eritrea's relation with the IGAD and the OAU/AU. Therefore, Eritrea's relation with the IGAD is discussed first to be followed by the discussion of the country's relation with the OAU/AU.

\section{Eritrea's Relation with the IGAD}

Eritrea joined IGADD, predecessor of IGAD, soon after it achieved dejure recognition in 1993. The country played important role in revitalization of the sub-regional body into a new institution called IGAD in $1996 .{ }^{14}$ Thus, at the time many were optimist of the newly born Eritrea's contribution for stability and increased cooperation in the region which was characterized by intertwined conflicts and mutual intervention. ${ }^{15}$

This hope begun to tremor when Eritrea's relation with another IGAD member, Sudan, started to become rough in $1994 .{ }^{16}$ With the regime change in Sudan after the 1989 coup d'etat, the new regime adopted radical Islamic ideas and supported Eritrean Islamic Jihad which carried out minor military attacks on western part of Eritrea. In response, Eritrea begun to support Sudanese armed groups and President Isaias declared that his regime will give weapons to any group committed to overthrow the Sudanese regime. ${ }^{17}$ And this led to creation of alliance between Eritrea, Ethiopia and Uganda till the outbreak of Ethio-Eritrean war intended to topple, or at least weaken, the regime in Khartoum. ${ }^{18}$

Another development that fundamentally shaped political landscape of the region and affected Eritrea's relation with the neighboring countries, the IGOs and international community at large was the Ethio-Eritrean war of 1998 to 2000. The war ended with military victory of Ethiopia and the two countries signed Algiers agreement in December 2000. The agreement established EthioEritrean Boundary Commission (EEBC) with the responsibility of demarcating boundary between the 
two states. The Commission, whose decision was agreed to be binding and final by the both sides, announced its verdict on April 2002 awarding the flash point of the conflict, Badme, to Eritrea.

Ethiopia rejected the ruling on December 2003 as the country won the war and controlled Badme. ${ }^{19}$ This led to beginning of stalemate between the two countries. Soon, Eritrea emerged disappointed by the failure of the larger international community to realize the ruling of the EEBC and started to pursue proxy war against Ethiopia using dissident groups within Ethiopia and Somalia. Thus, the Ethio-Eritrean war gradually undermined Eritrea's regional policy and marked the beginning of isolation of the regime in Asmara. ${ }^{20}$

The third major factor that affected Eritrea's relation with the neighboring countries, the IGAD and the international community at large was Ethiopia's military intervention in Somalia against the Union of Islamic Courts (UIC) in support of the Transitional Federal Government. Eritrea angrily opposed the intervention and found herself allied with the UIC. Eritrea's alliance with the UIC, which was categorized as fundamentalist organization by the US with links to al-Qaeda, in turn angered the IGAD member states. IGAD not only failed to oppose the intervention, as the Eritrean regime wished, but also approved it; leading to Eritrea's self-suspension from the organization in Aril 2007.

In June 2008, IGAD accused Eritrea due to her military attack on Djibouti. ${ }^{21}$ In February 2010, the organization welcomed UN sanction on Eritrea under the Resolution 1908(2009) which was adopted as a result of the country's alliance with the armed groups battling the federal government of Somalia. ${ }^{22}$ In June 2011, the IGAD Council of Ministers adopted a communiqué ${ }^{23}$ which condemned Eritrea for her support of extremist and subversive groups in the sub-region. In addition, the communique called the AU and the UN Security Council to take appropriate measures against the regime in Asmara and follow-up implementation of the existing sanctions. This decision of the IGAD Council of Ministers was adopted by the eighteenth ordinary session of the Assembly of IGAD on July 2011 and was finally referred to the AU Peace and Security Council and the UN Security Council. ${ }^{24}$

Generally, Eritrea which was believed to be source of strengthened cooperation in the subregion under the umbrella of revitalized IGAD soon emerged as source of difficulties. The country's relationship with the neighboring states and the IGAD, as an intergovernmental institution, witnessed radical turnaround from active and constructive engagement during the early years of independence to resortion to military means and finally exit from the sub regional cooperative framework. After four years of absence from the sub-regional forum, Eritrea announced, on July 2011, that it rejoined the sub-regional body though IGAD hasn't formally readmitted the country. ${ }^{25}$ The failure of immediate readmission to IGAD is argued as due to Ethiopia's deliberate obstruction. ${ }^{26}$

\section{Eritrea's Relation with the OAU/AU}

In similar vein to her relation with the IGAD, Eritrea's relation with the OAU and its successor the AU is characterized by difficulties. The first formal interaction between the OAU and the independent Eritrea came in 1992 after the setting up of Provisional Government of Eritrea. Up on invitation by the provisional government, the OAU sent a delegation to visit Eritrea and announced its readiness to observe the 1993 independence referendum. ${ }^{27}$

As it promised, the OAU sent an eighteen member observer team led by Senegalese Papa Louis Fall to attend the referendum and the team declared the referendum was fair, free and devoid of significant irregularities in its final statement. ${ }^{28}$ Within few months, the organization accepted Eritrea as its fifty second member state and the country assigned a permanent representative to the 
organization. These all show that Eritrea's relationship with the organization was normal during the early years of independence.

Nevertheless, this trend didn't last for long. President Isaias on his first address to the OAU Assembly as the leader of the independent Eritrea discarded the organization arguing that much of the past three decades of the OAU were absolute failure. ${ }^{29}$ The President further put that Eritrea's membership of the OAU wasn't because of the organization's impressive achievements but only "...in the spirit of familial obligation". ${ }^{30}$ Thus, Eritrea's relationship with the OAU begun to witness hardships in no more than few years after the country achieved its political independence via the OAU observed referendum.

Ethio-Eritrean war was the major root for Eritrea's non-amicable relation with the continental organization and its successor. The Algiers agreement was brokered by the OAU. Under the terms of Algiers agreement, specifically Article 14, the OAU was among the major stakeholders set responsible for implementation of decisions of the EEBC. After the Commission gave its verdict in favor of Eritrea, Eritrea sought the OAU and other bodies to enshrine their responsibilities as provided by the agreement.

Upon the failure of the OAU/AU and other bodies like the UN and the US to criticize Ethiopia for not accepting the decision of the EEBC, Eritrea's frustration begun to come to the scene and the OAU, later the AU, begun to be regarded as both powerless and unsympathetic to issues affecting Eritrea by the Eritrean government. ${ }^{31}$ In opposition to 'inaction' of the regional body to realize the verdict of the Commission and also given the forthcoming call for sanctions, Eritrea pulled out of the organization in December 2007. ${ }^{32}$

This situation was further worsened after allegations that Eritrea is supporting armed groups in Somalia which fight the Transition Federal Government; thus halting efforts being made by the AU and the larger international community to recapitalize peace in war torn Somalia, started to spread. As a result, in July 2009 Assembly of the AU requested ${ }^{33}$, upon earlier request by the IGAD and the recommendation of its Peace and Security Council, the UN Security Council to set sanctions on Eritrea for her alleged support of the armed groups in Somalia engaged in destabilization of the country. ${ }^{34}$

In February 2010, the AU Assembly welcomed UN Security Council Resolution 1907(2009) which called for arms embargo, travel restrictions and freezing of assets of Eritrea's top leaders for the regime's involvement in destabilization of Somalia and the region at large. ${ }^{35}$ This decision was first of its kind in history of the organization in that the AU called for sanction against its own member state. In July 2012, the AU again reiterated ${ }^{36}$ its determination to take measures against all those whose action is undermining the peace process in Somalia, largely meant Eritrea, and paid tribute to troop contributing and interested states, implicitly the list included Ethiopia, and to the IGAD.

To worse, the Eritrean regime was found responsible for planned massive bombing of Addis Ababa during sixteenth ordinary session of the AU Assembly held in January 2011. The regime's involvement in the plan was proved by the UN Monitoring Group on Somalia and Eritrea (UNMGSE) and the group reported that the operation was "...conceived, planned, supported and directed by the external operations directorate of the Government of Eritrea". ${ }^{37}$ The failed plot was seriously considered by the UN Security Council and laid basis for the Resolution 2023(2011) which strongly condemned the planned attack and set new sanctions targeted at the mining sector and other financial sources of the regime.

These all shows how Eritrea's relation with the AU and its predecessor OAU was rough and largely conflictual. After years of diplomatic isolation from the regional IGO, Eritrea rejoined the organization in January 2011 with appointment of Girma Asemerom as the new ambassador to the 
AU. ${ }^{38}$

Generally, the above two subsections clearly provided the basic nature of Eritrea's relation with the IGAD and the OAU/AU. As it was seen, the state's relationship with the two IGOs is problematic. In recent years, the Eritrean regime started to 'normalize' its relationship with the two IGOs given the ever increasing domestic instability accompanied with growing disagreement of the I 6 regime with Somali militant groups and the political and economic costs of the regional diplomatic isolation. ${ }^{39}$ In addition, downfall of the regime's major patrons, particularly Colonel Gaddafi and Hosni Mubarek, can be put as additional factor.

\section{Eritrea's Uneven Relation with the IGAD and the OAU/AU: The Explanatory Factors}

This section examines factors which explain Eritrea's rough relation with the IGAD and the OAU/AU. The major developments which provide important explanation for the nature of the country's relation with the two IGOs include centralized foreign policy making, legacy of the independence struggle, Eritrean government's resort to force, the Ethio-Eritrean war and the US-led 'war on terror'.

\section{Centralized Foreign Policy Making and Implementation}

One of the characteristic features of independent Eritrea's foreign policy is the highly centralized decision making under the direct control of the President. Though Ministry of Foreign Affairs is existent, it is the President's Office that essentially determines the country's foreign policy and its conduct. ${ }^{40}$ As a show case of the President's detrimental role in Eritrean foreign policy decision making, the country's Foreign Affairs Minister in the mid-1990s, Petros Solomon, was never consulted and also informed about the decision to cutoff diplomatic relation with Sudan in 1994 and the minister was made aware about the conflict with Yemen a year after the confrontation was onset and the war was started. ${ }^{41}$

Concentration of foreign policy decision making and implementation on the hand of the President and the few personally appointed advisors made the policy to be highly unpredictable, lowered well informed consideration of different alternatives and their possible implications, and retarded development of the functioning institutions. ${ }^{42}$ Thus, Eritrea's reckless decisions with regards to her membership in the IGAD and the AU can be partly explained by the nature of foreign policy decision making environment of the country.

\section{Legacy of Independence Struggle and Deep Rooted Sense of Betrayal}

Independence of Eritrea came after bitter struggle for over three decades. Throughout the long and bloody path to independence, sense betrayal by the outside world was deeply rooted going as back as the immediate years after the Second World War. When many of the colonies of the Axis powers were granted independence after the war, Eritrea was put under the British rule and later transferred to imperial Ethiopia; when emperor Hailesellessie dissolved the UN designed federal arrangement in 1962 , the UN and all the major powers kept silent; during the peak time of Eritrean struggle, Ethiopia was backed by the Soviet Union and the Eritrean rebels have had no significant international support and when Ethiopia rejected the original terms of settlement by the EEBC, the responsible IGOs and the major powers failed to put pressure on Ethiopia to be abided by the decision of the Commission. 
These all experiences since the mid-1940s led to development of a "...peculiar psychology in Eritrean society, characterized by a sense of abandonment, neglect and indeed betrayal". ${ }^{43}$

For the most part, Eritrea's lack of compassion with the OAU, and later with the AU, is built on indifference of the organization to the independence struggle. Ethiopia, particularly under emperor Hailesellassie, managed to cutoff any possible African support to the Eritrean struggle by presenting it as a pro-independence movement antithesis to territorial integrity of a member state. ${ }^{44} \mathrm{Up}$ on their failure to enlist support from the OAU and African states, Eritrean rebels managed to receive assistance from the Arab states. This alignment with the Arab states was presented by the Ethiopian government as a showcase of their instrumentality of Arab expansionism. ${ }^{45}$ The cumulative effect was precedence of the belief that "...if you trust no one, you can ally with anyone" among the Eritrean policy makers. ${ }^{46}$ Thus, historical experience of manipulation and neglect negatively affected the country's relation with the neighboring states and her participation in the IGAD and the OAU/AU.

\section{Eritrean Government's Resort to Force and Failure to Bargain}

Another factor which explains Eritrea's rough relation with its neighboring states, the IGAD and the OAU/AU is the unwarranted belief on military power as the best means to achieve the national goals. Beginning from mid-1990s, the Eritrean leadership started to be convinced that Eritrea can project its influence far beyond her borders militarily ${ }^{47} .^{48}$ As a result, the country which was believed to be catalyst for strengthened cooperation in the sub-region turned to be source of instability within few years. For worse, the new leadership lacked experience of achieving political goals through diplomacy and suffered from lack of institutionalized practice in this regard. ${ }^{49}$ This lack of diplomatic skills made the regime to appear aggressive ${ }^{50}$ And through time a "... warrior culture which sees diplomacy and willingness to negotiate as weakness" begun to prevail within the ranks of the Eritrean regime. ${ }^{51}$

The overall diplomatic backsliding was furthered by self-exclusion from various IGOs like the AU and IGAD accompanied with diplomatic ascendance of the Eritrean regime's adversaries, particularly Ethiopia. Thus, the Eritrean regime's favor to use of force and either its failure to make foreign policy decisions upon critical examination of the alternatives and/or miscalculation of the possible outcomes of its foreign policy actions opened the room for diplomatic alienation of the country to the extent of being called 'North Korea of Africa.'

\section{Ethio-Eritrean War and Its Consequences}

One of, may be the most fundamental, the explanatory factors for Eritrea's uneven relation with the neighboring states and the two IGOs is breaking of early alliance with Ethiopia as a result of the Ethio-Eritrean war. Immediately after the achievement of independence, Eritrea maintained normalized relation with Ethiopia on basis of cooperation and interdependence. Various agreements were signed in due consideration of the vital needs of the two countries i.e. Ethiopia's quest for access to the sea and the Eritrea's quest for a reliable economic partner. ${ }^{52}$ Despite these, hostility between the two countries begun to surface after the mid-1990s and reached climax with the destructive 'border war'.

The two regimes pursued policies aimed at weakening the other and the commonly used policy of subversion and alliance building begun to characterize their relations. The Eritrean regime allied itself with various dissident groups within Ethiopia and the nearby Somalia with overarching intention of weakening its Southern neighbor. The Ethiopian regime retaliated by supporting various 
Befekadu Bogale

Eritrean armed groups, forming alliances like the Sana'a forum ${ }^{53}$ aimed at isolating Eritrea and successfully used IGAD, the AU, the UN and the US to isolate the Eritrean regime and bypass possible strain related to realization of the EEBC ruling. Success of the Ethiopian regime in this regard deep entrenched Eritreans' traditional sense of being betrayed by the outside world and paved the way for the country's isolation from the sub-regional and the regional IGOs.

\section{Global 'War on Terror' and Ethio-US Alliance}

At the system level, the US declared 'war on terror' and Ethiopia's emergence as one of the major US allies in this project played its part for Eritrea's diplomatic isolation and backsliding from the subregional and regional IGOs. Eritrea, along with Ethiopia, was among the few African states the US identified as her major post-cold war partners in the continent. But after the border conflict between the two countries and onset of strong criticisms against the US by the Eritrean regime for the former's 'failure' to pressurize Ethiopia to be in line with the terms of Algiers agreement, relationship between the US and Eritrea begun to deteriorate. ${ }^{54}$ This allowed Ethiopia to emerge as a key US ally in 'war on terror' in the horn of Africa.

As a show case of strengthened Ethio-US alliance, the later supported Ethiopia's intervention into Somalia in 2006 and accused the Eritrean regime of supporting the radical groups in Somalia. ${ }^{55}$ In this way, Ethiopia found herself closer to the US and managed to get the boundary problem with Eritrea to be left as less demanding issue of the time. In opposite, Eritrea distanced herself from the world's only superpower and her quest for active US role to realize the EEBC's ruling was failed.

\section{Conclusion}

This article tried to examine the dynamics of Eritrea's relation with the IGAD and the OAU/AU using different factors from the individual, state and system levels. At the individual level, the role of Eritrean President Isaias Afeworki and his strong presence in foreign policy making and implementation is an important explanatory factor for overall ups and downs in the country's foreign policy and relations at large and her relations with the IGAD and the OAU/AU in particular.

At the state level, legacy of the Eritrean independence struggle and development of sense of betrayal by the outside world, the country's failure to solve disagreements with the neighboring states diplomatically and resort to force and overstating of the country's capacity to project its influence within the region and beyond needs to be mentioned.

At the system level, the US-led 'war on terror' and the establishment of strategic alliance in the region to benefit of the Ethiopian regime and at the expense of its Eritrean counterpart bears an important place in explaining the zigzagging of Eritrea's foreign policy and relations at large and her relations with the IGAD and the OAU/AU in particular. Added to this is the relative success of the policy of Ethiopia targeted at isolating the Eritrean regime using her position within the IGAD and the AU, and her strategic relation with the US and the western countries at large.

Therefore, as it was clearly indicated before, the domestic and international factors at all the three levels of analysis cumulatively provide holistic explanation for the question why Eritrea's relation with the IGAD and the AU is characterized by ups and downs since the mid-1990s. To be more specific, the domestic factors vehemently explain the unstable nature of Eritrea's relation with the two IGOs and the outside world at large. 


\section{Notes}

${ }^{1}$ Margaret Karns and Karen Mingst, International Organizations: The Politics and Processes of Global Governance (New York: Lynne Rienner Publishers, 2010), 5.

${ }^{2}$ Karns and Mingst, International Organizations, 5-7.

${ }^{3}$ Karen A. Mingst, Essentials of International Relations (New York: W.W Norton and Company, 2003), 227229.

${ }^{4}$ The six founding states of the IGADD are Djibouti, Ethiopia, Kenya, Somalia, Sudan and Uganda.

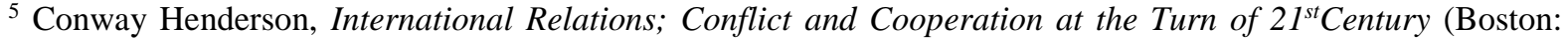
Mc-Graw Hill, 1998), 24.

${ }^{6}$ K.J. Holsti, International Politics; A Framework for Analysis (New Jersey: Prentice-Hall, 1995), 18.

${ }^{7}$ Marijke Breuning, Foreign Policy Analysis: A Comparative Introduction (New York: Palgrave Macmillan, 2007).

${ }^{8}$ Breuning, Foreign Policy Analysis, 12-13.

9 Holsti, International Politics; Breuning, Foreign Policy Analysis; Alex Mintz and Karl DeRouen, Understanding Foreign Policy Decision Making (Cambridge: Cambridge University Press, 2010).

${ }^{10}$ David Singer, "The Level of Analysis Problem in International Relations," in The International System:

Theoretical Essays, eds. Klaur Knorr and Sidney Verba (New Jersey: Princeton University Press, 1961), 85.

${ }^{11}$ Breuning, Foreign Policy Analysis, 13.

${ }^{12}$ Holsti, International Politics; Mark Webber and Michael Smith, Foreign Policy in a Transformed World (Harlow, UK: Pearson Education Limited, 2002).

${ }^{13}$ Holsti, International Politics; Webber and Smith, Foreign Policy in a Transformed World; Mintz and DeRouen, Understanding Foreign Policy.

${ }^{14}$ Mengisteab Kidane, "What has gone wrong with Eritrea's Foreign Relation?" in Eritrea's External Relations; Understanding Its Regional Role and Foreign Policy, ed. Richard Reid (London: Chatham House, 2009), 45.

${ }^{15}$ Tadesse Medhane, Turning Conflict into Cooperation: Towards an Energy-Led Integration in the Horn of Africa (Addis Ababa: Friedrich-Ebert-Stiftung, 2004).

${ }^{16}$ Kibreab Gaim, "Eritrean-Sudanese Relations in Historical Perspectives," in Eritrea's External Relations; Understanding Its Regional Role and Foreign Policy, ed. Richard Reid (London: Chatham House, 2009).

${ }^{17}$ Tanja Muller, "Understanding the Dynamics of Foreign Policy-Making in a New State: The Case of Eritrea," in Globalization and Emerging Trends in African Foreign Policy; A Comparative Perspective of Eastern Africa, eds. Korwa Adar and Peter Schrader (Maryland: University Press of America, 2007), 33.

${ }^{18}$ Gaim, "Eritrean-Sudanese Relations," 91; Mesfin Berouk, "The Horn of Africa Security Complex," in Regional Security in Post-Cold War Horn of Africa, eds. Roba Sharamo and Mesfin Berouk (Pretoria: ISS, 2011), 18.

${ }^{19}$ Bereketeab Redie, "The Eritrea-Ethiopia Conflict and the Algiers Agreement: Eritrea's Road to Isolation," in Eritrea's External Relations; Understanding Its Regional Role and Foreign Policy, ed. Richard Reid (London: Chatham House, 2009), 111.

${ }^{20}$ Kidane, "What has gone wrong," 61.

${ }^{21}$ The allegation was summarized in the Communique of the $12^{\text {th }}$ Summit of the Assembly of IGAD which was adopted on June 14, 2008 in Addis Ababa.

${ }^{22}$ This decision of IGAD was included in the Communique of the $34^{\text {th }}$ Extra-Ordinary Session of the IGAD Council of Ministers which was adopted on February 1, 2010 in Addis Ababa.

${ }^{23}$ The communiqué was titled 'the Communique of the $39^{\text {th }}$ Extra-Ordinary Session of the IGAD Council of Ministers' and adopted on June 28, 2011 in Malabo.

${ }^{24}$ The decision appears in the Communique of the $18^{\text {th }}$ extra-ordinary session of the Assembly of IGAD which was adopted on July 4, 2011 in Addis Ababa.

${ }^{25}$ David Shinn, "Eritrea's Regional Relations," The International Policy Digest, August 17, 2012, accessed December 3, 2012, http://www.internationalpolicydigest.org /2012/08/17/eritreas-regional-relations/.

${ }^{26}$ Tekle Tesfa-Alem, "Eritrea accuses Ethiopia of obstructing its efforts to rejoin IGAD," Sudan Tribune, Sunday November 4, 2012 accessed 01 February 2013, http://www.sudantribune.com/spip.php?article44412.

${ }^{27}$ Iyob Ruth, The Eritrean Struggle for Independence; Domination, Resistance, Nationalism $1941 \quad$ - 1993 (Cambridge: Cambridge University Press, 1995), 137.

${ }^{28}$ Ruth, The Eritrean Struggle, 140. 
${ }^{29}$ Heally Sally, "Hard and Soft Power: Some Thoughts on the Practice of Eritrean Foreign Policy" in Eritrea's External Relations; Understanding Its Regional Role and Foreign Policy, ed. Richard Reid (London: Chatham House, 2009), 153.

${ }^{30}$ Michela Wrong, I Didn't Do it for You: How the World Betrayed a Small African Nation (New York: Harper Collins, 2005), 358.

| $10 \quad{ }^{31}$ Redie, "The Eritrea-Ethiopia Conflict," 120.

${ }^{32}$ Kidane, "What has gone wrong," 66.

${ }^{33}$ The request was included in the Resolution of $13^{\text {th }}$ Ordinary Session of the Assembly of the AU which was adopted on July 3, 2009 in Sirte Libya.

${ }^{34}$ BBC, "AU calls for Sanctions on Eritrea," BBC World Service, May 23, 2009, accessed January 7, 2013, http://news.bbc.co.uk/2/hi/8064939.stm.

${ }^{35}$ The Union's final statement was included in the 'Decision of the $14^{\text {th }}$ Ordinary Session of the Assembly of the AU' which was adopted on February 2, 2010 in Addis Ababa.

${ }^{36}$ This decision of the AU Assembly was included in the Resolution of the $19^{\text {th }}$ Ordinary Session of the Assembly of AU which was adopted on July 16, 2012 in Addis Ababa.

${ }^{37}$ UN, "Report of the UN Monitoring Group on Somalia and Eritrea," March 26, 2011, accessed January 3, 2013, http://www.un.org/ga/search/view_doc.asp?symbol=S/2011/433.

${ }^{38}$ Shinn, "Eritrea's Regional Relations"

${ }^{39}$ Shinn, "Eritrea's Regional Relations"

${ }^{40}$ Muller, "Understanding the Dynamics of Foreign Policy-Making," 45; Dan Connell, "Eritrea and the United States: Towards a new US Policy," in Eritrea's External Relations; Understanding Its Regional Role and Foreign Policy, ed. Richard Reid (London: Chatham House, 2009).

${ }^{41}$ Connell, "Eritrea and the United States"

${ }^{42}$ Kidane, "What has gone wrong," 49.

${ }^{43}$ Redie, "The Eritrea-Ethiopia Conflict," 118.

${ }^{44}$ Redie, "The Eritrea-Ethiopia Conflict," 119.

${ }^{45}$ Ruth, The Eritrean Struggle for Independence, 54-55.

${ }^{46}$ Connell, "Eritrea and the United States," 42.

${ }^{47}$ This assertion of the Eritrean regime is mainly rooted in the Eritreans' military success on the Dergue which maintained one of the largest and the most equipped military force in the sub Saharan Africa.

${ }^{48}$ Medhane, Turning Conflict into Cooperation, 38-39; Sally, "Hard and Soft Power," 151.

${ }^{49}$ Sally, "Hard and Soft Power," 153.

${ }^{50}$ Kidane, "What has gone wrong," 61.

${ }^{51}$ Healy Sally, "Eritrea's Regional Role and Foreign Policy: Past, Present and Future Perspective," Chatham House Report, January 2008, accessed December 13, 2012, www.chathamhouse.org/sites/default/files/public/.../171207eritrea.pdf.

${ }^{52}$ Ruth, The Eritrean Struggle for Independence, 143.

${ }^{53}$ It has to be recalled that the Sana'a forum was established by Ethiopia, Sudan and Yemen (all the three states engaged in confrontations of differing scale with the Eritrean regime) in 2002.

${ }^{54}$ Kidane, "What has gone wrong," 64.

${ }^{55}$ Kidane, "What has gone wrong," 67.

\section{References}

\section{Books and Book Chapters}

Berouk, Mesfin. "The Horn of Africa Security Complex." In Regional Security in Post-Cold War Horn of Africa, edited by Roba Sharamo and Mesfin Berouk, 1-30. Pretoria: ISS, 2011.

Breuning, Marijke. Foreign Policy Analysis: A Comparative Introduction. New York: Palgrave Macmillan, 2007.

Connell, Dan. "Eritrea and the United States: Towards a new US Policy." In Eritrea's External Relations; Understanding Its Regional Role and Foreign Policy, edited by Richard Reid, 131-149. London: Chatham House, 2009.

Gaim, Kibreab. "Eritrean-Sudanese Relations in Historical Perspectives." In Eritrea's External Relations; Understanding Its Regional Role and Foreign Policy, edited by Richard Reid, 71-97. London: Chatham House, 2009. 


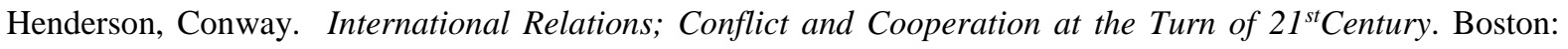
Mc-Graw Hill, 1998.

Holsti, K.J. International Politics; A Framework for Analysis. New Jersey: Prentice-Hall, 1995.

Karns, Margaret and Karen Mingst. International Organizations: The Politics and Processes of Global Governance. New York: Lynne Rienner Publishers, 2010.

Kidane, Mengisteab. "What has gone wrong with Eritrea's Foreign Relation?" In Eritrea's External Relations; Understanding Its Regional Role and Foreign Policy, edited by Richard Reid, 45-70. London: Chatham House, 2009.

Medhane, Tadesse. Turning Conflict into Cooperation: Towards an Energy-Led Integration in the Horn of Africa. Addis Ababa: Friedrich-Ebert-Stiftung, 2004.

Mingst, Karen A. Essentials of International Relations. New York: W.W Norton and Company, 2003.

Mintz, Alex and Karl DeRouen. Understanding Foreign Policy Decision Making. Cambridge: Cambridge University Press, 2010.

Muller, Tanja. "Understanding the Dynamics of Foreign Policy-Making in a New State: The Case of Eritrea." In Globalization and Emerging Trends in African Foreign Policy; A Comparative Perspective of Eastern Africa, edited by Korwa Adar and Peter Schrader, 27-51. Maryland: University Press of America, 2007.

Redie, Bereketeab. "The Eritrea-Ethiopia Conflict and the Algiers Agreement: Eritrea's Road to Isolation." In Eritrea's External Relations; Understanding Its Regional Role and Foreign Policy, edited by Richard Reid, 98130. London: Chatham House, 2009.

Ruth, Iyob. The Eritrean Struggle for Independence; Domination, Resistance, Nationalism 1941 - 1993. Cambridge: Cambridge University Press, 1995.

Sally, Heally. "Hard and Soft Power: Some Thoughts on the Practice of Eritrean Foreign Policy." In Eritrea's External Relations; Understanding Its Regional Role and Foreign Policy, edited by Richard Reid, 150-160. London: Chatham House, 2009.

Singer, David. "The Level of Analysis Problem in International Relations." In The International System: Theoretical Essays, edited by Klaur Knorr and Sidney Verba, 77-83. New Jersey: Princeton University Press, 1961.

Webber, Mark and Michael Smith. Foreign Policy in a Transformed World. Harlow, UK: Pearson Education Limited, 2002.

Wrong, Michela. I Didn't Do it for You: How the World Betrayed a Small African Nation. New York: Harper Collins, 2005.

\section{Website Sources}

BBC. "AU calls for Sanctions on Eritrea." BBC World Service, May 23, 2009. Accessed January 7, 2013. http://news.bbc.co.uk/2/hi/8064939.stm.

Sally, Healy. "Eritrea's Regional Role and Foreign Policy: Past, Present and Future Perspective," Chatham House Report, January 2008. Accessed December 2012. www.chathamhouse.org/sites/default/files/public/.../171207eritrea.pdf.

Shinn, David. "Eritrea's Regional Relations," The International Policy Digest, August 17, 2012. Accessed December 3, 2012. http://www.internationalpolicydigest.org /2012/08/17/eritreas-regional-relations/.

Tesfa-Alem, Tekle. "Eritrea accuses Ethiopia of obstructing its efforts to rejoin IGAD." Sudan Tribune, Sunday November 4, 2012. Accessed February1, 2013. http://www.sudantribune.com/spip.php?article44412.

UN. "Report of the UN Monitoring Group on Somalia and Eritrea," March 26, 2011. Accessed January 3, 2013. http://www.un.org/ga/search/view_doc.asp?symbol=S/2011/433. 